\title{
Synaesthetic Without Sensitivity? The Body as a Technological Construction
}

\author{
Žarko Paić \\ University of Zagreb, Zagreb, Croatia
}

\begin{abstract}
Since technology transformed itself into something uncanny what determines human civilization from modern times, nature has already transformed into a pure technological creation. The time of contemporary art corresponds to everything that quantum mechanics has set up based on the new understanding of the universe. From artworks of John Cage, Samuel Beckett, and Maurice Blanchot to performative-conceptual artworks of Stelarc and Ken Rinaldo, we are permanently witnessing the inability to return to the "aesthetics of stability" of the world. The whole circuit within cybernetic self-development, self-turn around, and self-organization of technosphere is reduced to three key theoretical concepts and paradigms of contemporary research in the field of A-intelligence, A-emotion, and A-intuition. Those are (1) contingency; (2) singularity; and (3) emergent chaos. Unlike technique that belongs to the mechanical perception of nature as a machine of organic world reproduction, a technology that in the modern era enters the field of semi-automatic and automatic mode of machine operation, in the age of technosphere, we are faced with the transfer to telepresence spaces (Marvin Minsky) and tele-existence (Susumu Tachi). Information transfer and manage remote systems by means of code become the condition of possibility of interaction in the technical world. If the question of ontology has been focused on the object and its idea of autonomy, then it is obvious that it could not be "the one" facility with which it dealt concerning the metaphysics of subjectivity from Descartes to psychoanalysis. It is an object or thing that thinks in a completely distinctive way, unlike human thought. For that reason, instead of the "embodiment”, it carries out the function of “embeddement”.
\end{abstract}

Keywords: synaesthetic, body, technosphere, Stelarc, Rinaldo, singularity, interaction

\section{Introduction: Aesthetics in the Age of Technosphere}

During the 1960s when cybernetics, informatics, semiotics, communication, and media science (including their application in practice of robotized life) came directly into the technical world, Max Bense has already written a new aesthetics. Undoubtedly, it was obvious that almost all the notable philosophers of the famous metaphysics from Plato to Hegel must be reinterpreted. But with the possibility of constantly reinterpreting the old concepts, it was much more significant to see what is meant by the possibility of aesthetics giving a different meaning to its usual meaning. According to such a view, art does not appear merely as a privileged subject of reflection, but also as the exclusive right of aesthetics that art alone determines the rules of the game. The terms appropriated by aesthetics have appeared in the modern era, but of course, they were by ancient origin. Their origins inherited from very arché of Greek philosophy. To a lesser extent, it also concerned the

Žarko Paić, Dr., professor of Aesthetics and Media Theory, Department of Fashion Design, Faculty of Textile Technology, University of Zagreb, Zagreb, Croatia. 
Roman understanding of the world. The work of art with the pleasure of participating in the common manifestation of the truth is the antiquity being deriving from the mythical-religious festivity. It was an event of the relationship between gods and people in the city-state (polis) based on the assumptions of the cult. But it could be, then, that the renaming of a primordial event into the reference frame of natural-scientific observation of the thing itself as a subject matter has marked the transition from the openness of the event to the closed reflection structure. In addition, the space for the authentic communion of human interactions has provided nation-state boundaries with the cosmopolitan ideals of the world understood by the scientific-technical horizon. The modern age extended the idea of beauty to purposefulness without purpose. That is Kant's ultimate definition from Critique of Judgment (Kritik der Urteilskraft) (Kant, 1979). According to Kant, aesthetics belong to the same consideration system as a reflection of the power of judgment and logic as nature teleology. In principle, that means how the new metaphysics of subjectivity acts as a projection of a good thing into what the subject did not have on its own (an-sich) but is attributed to it by the simple act of reflection. It could be named the own beginning of a great work of construction in the emergence of the entire technical world. In the very core of high modernity, the process of the aestheticization of the world has taken its place (Welsch, 1996).

The beauty and sublime now become the remnants of the secularized theology of divine grace in the world derived from the rational environment of thought. Its definition is derived from computing (Rechnen). The calculation involves the planning and construction of things and excludes so-called invariable nature reflected in the spin of the new times. In essence, such an opinion has determined mathesis as the internal and external limit of self-the fulfilment of the subject. It was already accepted among explorers within the philosophy that aesthetics in the modernity is derived from the spirit of rationalism. Along the way, it can be noted that the pertinent style of thinking means the construction of other nature and the beginning of the degradation of the historical being of the human. Everything that can be constructed on the basis of the work of imagination might be also simultaneously deconstructed. The purpose (teleology) of nature signifies, therefore, the plainness of history, but also the hidden possibility of the end of the grandiose illusion of metaphysics. How much is the idea of the purposefulness of the Being involved in the thought of the plantings, even Darwin's theory of biological evolution, and in particular in the theory of life of plants and animals (Umwelt-environment)? The answer would be very short and clear: It is located at the bottom of the whole evolutionary matrix! Therefore, the world is neither perfect nor does it necessarily carry out the empire of beauty. Its mystical background lies deeply hidden in the fact of forming the idea of harmony between encompassing beings. It should be quite possible to attribute rationality and balance to nature and to give humans the opportunity to realize the ideal of perfect harmony between nature and Being by rational thinking and action.

When Max Bense seeks to preserve the term and word of aesthetics, he had primarily a vague idea of what has happened with that change in the reference framework. We found ourselves in the most sophisticated terms of the description, which makes the overall sense of aesthetics in a technically designed world.

Each transcendental theory of consciousness (in the sense of G. Günther) belongs to a more general metaphysical theory within which correlative signs and correlative mechanics of communication (in the sense of the communication theory of Shannon and Wiener) make corrective. From this system of previous more general theories, aesthetics can be derived in terms of the theory of aesthetic Being. The consciousness not only transforms the signs which it receives, but it also produces them. Signs are the real products of consciousness, manifestations, information by which it declares itself. These free, original manifestations are objectives in the aesthetic Being. Only in the aesthetic production consciousness becomes truly a residuum of possible worlds in which there are the nature and objects, and the residual of the possible loss of the world, to which nature and objects are no longer needed. (Bense, 1978, p. 106) 
If anything that we are still usually naming aesthetics to stay alive in a collision with the logic of the technical world and should be still convicted of becoming a kind of last resort of the so-called the possible worlds of human existence with the illusion of "nature" and "objectivity", then the notion of aesthetics must be understood in the expansion of the area of corporeality or sensitivity. Of course, in the broader sense, that is the content of what philosophical aesthetics have had in mind from the 18th century in works of Baumgarten and Kant related to the basic notion of nature as the purpose of the Being. That was basically done by Max Bense at the very beginning of the rise of the technosphere. It would not be a big problem in finding the disappearance of the last remnants of modern aesthetics as "adventure" and "experience", but we shall still try to analyze the aesthetics of nature and destiny which occurred until now in that matters what Paul Virilio (1991) called the "aesthetics of disappearance". What is missing in that unsustainable process of technical conquest of the world through science and its associated method and experiment from which numerous devices and objects, semi-automatic and automatic machines were created, is precisely the world's worldhood. It was a human who gave meaning to philosophy and art. In the period of Anthropocene in which a human appears to be the ruler of industrial exploitation of the Earth, its depletion and total depletion to the last sources of unconventional energy, that paradox obviously still happens. Only the techno-genetic purified Being in the crystallized state of information as instructions for use in the network of events would be a salvific way of preserving what is left of the Earth and its spiritual-historical and natural-genetic sources for the future. Why does it happen and how can we manage it? Just as the techno-genesis comes out of the framework of metaphysical thinking of differences and oppositions, no dialectics anymore could be relevant, whether constructive or destructive, negative or open. When, in fact, it synthesizes what makes life alive in the form of an artificial substance of a Being, then all binary opposites are gone forever. What remains is just distinguishing the degree of intensity of power in understanding the Being as a becoming (Werden, devenir).

Should we make this assumption that in the age of technosphere, the aesthetical and the technical can no longer have the same kind of autonomy as the postulate of aesthetic modernity asserted by Adorno as the main thinker of negative dialectics, which we obtained as a result? Certainly, that was among the other thinkers in the age of cyberspace firstly advocated by Max Bense. Instead of aesthetic autonomy, we are incorporated in the techno-ethical heteronomy of the worlds. It does not appear as the "illusion" and "experience" of the reflexive observer. The doctrine of construction, which determines what will be and how an "autonomous object" may act as a substitute and addition to the aesthetic object that Marcel Duchamp ironically named "readymade", surpasses aesthetics and logic as a teleology (nature). Nature and subject matter, however, remain the remnants of the former worlds. But they are no longer relevant to technosphere. The reason lies in the fact that technologically created new nature has to be shaped in the form of artificial life $(A L)$. In the act of shaping the work, there is the trinity of the setup-design-concept. That unites the aesthetic and technical assemblage of Being. But now (not more analytically but synthetically), it became all the materials and forms of the world and life after the Anthropocene period. In contemporary art, hybridization should be observed in all the manifestations in which what is happening now articulate that art still makes the creative act of transforming the being as the nature of things. However, that is not true only for installation, performative and conceptual art. The "essence" of modern art is not more in the idea of a permanent and unchanging state of nature from which we evaluate whether something must be regarded as beautiful, sublime, harmonious, or perhaps just aesthetically appealing to human senses. Since technology transformed itself into something uncanny what determines human civilization from modern times, nature has already transformed into a pure technological 
creation. The time of modern art corresponds to everything that quantum mechanics has set up based on the new understanding of the universe. Nothing is absolutely nothing. Nor does it function in the plan of the transcendence. Everything happens in reminiscent of unambiguous characters. Why? Just because time goes beyond the oppression of actuality and perpetuation. It is obsessed with the idea of singularity as "progress" and "eternal return" gathered in the network of events without a predetermined purpose and plane. From artworks of John Cage, Samuel Beckett, and Maurice Blanchot to performative-conceptual artworks of Stelarc and Ken Rinaldo, we are permanently witnessing the inability to return to the "aesthetics of stability" of the world. There are, however, many surviving concepts inherited from our Western tradition. But they are merely guidelines for a different creation of a new creation logic, unlike those that marked the golden age of metaphysics.

What connects "beauty" and "construction" in an attempt to make a new aesthetically shaped constellation? A great achievement of modern philosophy made by Descartes, Leibniz, and Spinoza's systems, and Kant at the bottom is at the juncture of opinion that theoretically, practically and politically corresponds to the scientific-technical nature of its ideal of mathematics. From that viewpoint, we must say that it would be undeniable almost everything what has been a credo for Newton's paradigm. It could be also noted that faith determined a rational-purpose order of the universe. If the world is governed by God as a perfect being, arbitrariness is excluded. Aesthetics in all areas should represent the thought of the world. The produced world cannot have a meaning here unless there is the first cause of its creation with the ultimate purpose of existence. As we know, the thinking that will determine the fate of the modern technical world Kant has divided into the areas of transcendental and empirical, noumenal, and apparent fields of validity. However, this duality can only be considered as radically reversed medieval scholasticism on the new ground. And what was lacking in the idea of a new metaphysics of beauty and sublime has been the aesthetics and logic as teleology (nature) which filled the void. The God who gave Christian theology the reason for its survival by overwhelming the concept of Being with the omnipresent act of eternity and the creation of worlds has now to be replaced by rational proof of its existence. The act of unconditional faith in the transcendent field was no longer sufficient. Antinomies with the climax of ontological evidence of God's existence, which cannot be justified by a pure mind, are thus moved to an area of aesthetic thinking. Aesthetics started with Kant and he was the last authentically verified thinker who seriously advanced that uncanny epistemological abyss. The idea of constructing "purposiveness without purpose" was, after all, only a metaphysical construction of the concept without the possibility of logical and practical deduction. Beauty as the main concept of aesthetics has since become a techno-poetical creation. In all relevant post-Kantian attempts to preserve the meaning and purpose of the world from which beauty irretrievably disappeared as a reference framework of antique-medieval thinking, we can find this passion for technical substitution. Hans Blumenberg (2015) showed it impressively related to the assertion that organically created beings become a matter of technical construction. By the disappearance of opposites imitated and invented, we are coming into the period of the technical genesis of the world (pp. 27-29). Rather than imitating the nature of the discovery of its new possibilities of action in technical forms of being, they redirect their thinking into the technology of creating a new one.

In strongly distinguishing categories as technique, technology, and technosphere, it is possible by analogy to establish the following basic concepts and categories of aesthetics and contemporary art. We would be able to see how each other overlaps and coincides, as both dialectical logic has lost either-or and, in its place comes the transduction logic of cybernetics and either-too operating systems. What is valid, for example, to find the 
essence of the technical world is also true of creativity in the core of the artistic production of the "truth" protocol, nevertheless, no longer as a confirmation of being and consciousness, but as a construct of an event based on the idea of pure contingency.

(1) The technique already means the mechanical reproduction of the being. Its logic is based on the imitation process of the machine subsequent to the natural skeleton of the human body. As in the modern metaphysics of subjectivity, it is called res extensa, referring to the potential infinity of matter extension. The machine within this mechanical paradigm of nature "works" as a human body. Therefore, the technique always follows such constructed tools in service for an external purpose. The nature, like in Kant's system, shows a meaningful activity. It provides the illusion of beauty and the exaltation of sublime (Erhabenheit) with the highest point in the artwork as an imitation of the harmony of nature in contemplation. The aesthetics that follow the idea of modern technique and the rationalism of natural sciences can only be the aesthetics of Schein and Erlebnis and observer has a strict role being a rational subject. Its character is fundamentally different from the character of a scientist who, like Newton or Galileo, has been observing galactic telescopes in the universe and mathematically calculates the legality in nature as the applicability of God's revelation. Leibniz expressed that in a famous and glorious attitude: Cum Deus calculat and cogitationem exercet, fit mundus. Each mechanical technique should be reproductive. And the aesthetics that relies on this implausible assumption of "progress" and "development" of nature in the form of a divinely constructed machine inspires ideas of productive imagination as creative thinking of the new. Creativity would be ultimately understood by the inventive activity because it imitates God and its mode of creation (imitatio Dei).

(2) Technology, however, is determined by the system of action of semi-automatic and automated techniques in industrial capitalism. Leading machines that involve the unity of the means-for-purpose are the steel locomotive and the car. Driving mode of modern technology is already assumed by thermodynamics and engineering. The machine is manufacturing organization, and, on the other hand, extends to the creation of the social structure of modernity: From the construction of railways and highways to airports and terminals, we witness the framework for dynamic relations between the masses and the individual. It is not just about the scientific-technical way of thinking that gives rise to the applicability of the technology. As Heidegger and particularly Benjamin demonstrated in their books, dealing with the relationship of modern technology and art, what happens when photography and film become the main media of contemporaneity is the disappearance of the aura or even the total disappearance of the category of artwork in the sense of originality and singularity. The reproductive essence of modern technology should be understood as the spirit of copy or replication of the original. Everything can be duplicated into infinity. The reason is that the machine which works on the principles of thermodynamics and engineering has become a model of the organization of the mass society and culture. Therefore, aesthetics was appropriate to the age of modern technology determined by the categories of mass and reproducibility. Instead of the passive contemplation of the subject in the technical apparatus of classical aesthetics, the modern world is determined by the cinematic mode of production. Looking from the inside perspective, the subject becomes a massive producer and consumer. It must be added that the universal spectator creates the main object of the cultural industry or a society of the spectacle (Adorno-Debord) in such way that it transforms its leisure time into the continuation of working time. By capturing the visual perception of entertainment to the degree of emptiness and boredom in the infinite "progress" and "development" of the possessed desire, it creates a vicious circle of capital, aesthetics of the world, and infinite reproducibility of desire. Between the cinematic dream of technology and spectacle aesthetics exist a secret alliance based on 
mastering the conscience of the Other through new techniques of economic-cultural marketing (Lipovetsky \& Seroy, 2013). The entire 20th century has been marked by the "death of aesthetics". Consequently, there is no longer sufficient reason to preserve the artistic or aesthetic autonomy of the subject in the penetration of the mass copying techniques of the original. Instead, the rebellion of the object arises in the desire for the inconvenience of pure corporeal liberation from the tyranny of pure mind and the logical coherence of language. The performative art created by Dadaism in the early avant-garde movements during the First World War becomes the last area of aesthetics of the event. So, it precedes all other forms of contemporary art (Mersch, 2002).

(3) Technosphere can no more be thought out of the binary oppositions of classical metaphysics with its terms, such as "Being”, "substance”, "linearity”, “reciprocity”, and "symmetry”. French deconstructivists and poststructuralists (from Derrida through Lyotard to Deleuze and Stiegler) have already begun enhancing all these concepts by those who point to the cybernetics and semiotics. Simondon was the first who instead of the steadfastness of the being began to point to metastable balance in the nature of things. Instead of ontogenesis, he advocated the techno-genetic structure of objects in a series of events. All that was valid for the period of the modern reproductive matrix of technology based on the idea of infinite multiplication of the original is now shifted to the processes of creating "a lifetime". Therefore, instead of reproduction of the Being and the replication of things, a new way of cybernetic management of past history has been established without the purpose and the pre-existing God's plan of creation. The key is the one that links the information and genetic code-cloning. It must be a creative copying process as an opportunity to perfecting the species due to its subconsciousness by merging the biological nucleus and the technical structure of the genetic stem cell (DNA). For instance, manipulating the genes of prenatal selection to transgenic therapy raises the question of the use of technoscience for the purpose of therapeutic and reproductive cloning with regard to social boundaries in which occurs the process of creating a "brave new world". In a series of new forms and discourses of contemporary art, there are also those that explicitly referred to a new constellation as a genocentric and cognitive adaptation to the idea and practice of life. Among them, it will be necessary to distinguish postgenomics and transgenic art (Reichle, 2009).

The whole circuit within cybernetic self-development, self-turn around, and self-organization of technosphere is reduced to three key theoretical concepts and paradigms of contemporary research in the field of A-intelligence, A-emotion, and A-intuition. Those are (1) contingency; (2) singularity; and (3) emergent chaos. Unlike technique that belongs to the mechanical perception of nature as a machine of organic world reproduction, a technology that in the modern era enters the field of semi-automatic and automatic mode of machine operation, in the age of technosphere, we are faced with the transfer to "telepresence" spaces (Marvin Minsky) and "tele-existence" (Susumu Tachi). Information transfer and manage remote systems by means of code become the condition of possibility of interaction in the technical world. If the question of ontology has been focused on the object and its idea of autonomy, then it is obvious that it could not be "the one" facility with which it dealt concerning the metaphysics of subjectivity from Descartes to psychoanalysis. It is an object or thing that thinks in a completely different way, unlike human thought. For that reason, instead of "embodiment", it carries out the function of "embeddement”. Let us take quite an ordinary example. The chips replace the neurons of the brain, and the programming language of the information code is determined in the last instance of the interaction between different objects in the global "societies of control". By entering a technosphere in discourse and apparatus of the reflection, a new aesthetics of inhumane might be completely 
created. It seeks to cybernetically reflect on the conditions under which contemporary art could successfully "work" in the digital environment.

\section{Technogenesis and Symbiogenesis: Stelarc and Ken Rinaldo}

The Australian cybernetic performative artist Stelarc certainly represents one of the most significant contemporary actors of what the theory of superimposing traditional metaphysical oppositions of human and machine has been called posthumanism and transhumanism. Let us recall that, in the former case, it is the logic of the inhuman within the idea of overcoming the boundaries of human as a subject of history, with the emphasis on the possibility of creating a new genre/object of genetic engineering and robotics. In the latter case, transhumanism seeks to overcome the obsolescence of the biological body by using the latest technology of cryonics, 3D printers, chip installation, genetic selection, and nanotechnology. While cyborgization of life should be a matter of posthumanism, in the case of transhumanism, it is a matter of perfecting cybernetically created body as a relationship between human/humanoid and robot/android (Stelarc, 2016, pp. 427-456). They have become the curiosities of Stelarc's programmatic setting of "body obsolescence", of his "extraterrestrial existence", of the necessity of "extending cybernetic bodiliness", and of the fact that we have always been "prosthetic bodies" (Stelarc, 2016, pp. 428-430). Some will see that close relationship exists in between the development of technique and technology as a method and experiment with something which is no longer fixed by the difference between the "primordial" and the "other" nature. However, it seems to be much more significant in this regard to show something that is mostly not discussed when it comes to the intentions of contemporary art to record its time by giving it an authentic voice of justification and critical speech about its immanent boundaries.

The problem manifested here cannot be in full scale reduced to the distinction in-between "human" and "machine", biological and technical, and nature and culture. After all, in the core of Western metaphysics, it was clear that what the Greeks called hubris truly belongs to the "Big Third" area. In mythology, that term referred to the goddess of violence and power. Its essence is not derived from a one-off being as one but must be understood in the juncture of the two different substances. Exactly because of that, what was created by merging cannot be considered as pure being. The most prominent example of a fusion of incompatible has been, of course, a centaur (the head and body of a human and an extended body of a horse). However, hybridity in the case of contemporary art could not be very close to posthumanism and transhumanism as a result of the technological process of the production of new beings that do not exist in nature. It is the principle of construction established in the process of creating something that combines binary opposites by synthesizing them into the emergence of a new one without analogy with "being" as physiology. Hybridization, therefore, means a method and a procedure, not a result of the experiment in which it should be separated (two substances) and finally synthesized. If it happened, then we have to access so-called aesthetic thinking in the age of technosphere by abandoning everything that aesthetics has set since its formal emergence to the beginnings of cybernetics and techno-science. Why? The answer derives from the impossibility of establishing aesthetics as a philosophical reflection on art without the persistence of concepts, such as "the world”, "human”, "art”, and "aisthesis". What replaces the disintegration of the metaphysical scheme Being-God-World-Human in the age of technosphere has been quite evident in the artworks-events of contemporary cybernetic artists, such as Stelarc and Ken Rinaldo. The word-term in which the complexity event assembled on the edge of chaos is a body. To think of a body beyond the metaphysical language of speech as a word and letter, power and 
governing, transcendence and immanence, means to reach the openness of pure singularity. Without attempting to search for the substitute God of creation and the substitute nature of the matter, the body should be self-evident at the same time by the self-cultivating and the techno-genetic event. No one has said it more plastically in the manner of almost programmatic philosophical demand than Gilles Deleuze in the second volume of Cinema:

Give me the body, 'this is the formula of the philosophical turn. The body is no longer the obstacle that separates thought from itself, that which it has to overcome to reach thinking. It is o the contrary that which it plunges or must plunge into, in order to reach the unthought, that is life. Not that the body thinks, but, obstinate and stubborn, it forces us to think, and forces us to think what is concealed from thought, life. Life will no longer be made to appear before the categories of thought; thought will be thrown into the categories of life. The categories of life are precisely the attitudes of the body, its postures. "We do not even know what a body can do": in its sleep, in its drunkenness, in its efforts and resistances. To think is to learn what a non-thinking body is capable of, it’s capacity, its postures. (Deleuze, 1989, p. 189)

In an auto-reflexive process of breaking down its own performance practice as a human-cyborg in relation to robustly constructed machines, Stelarc has shown us that the body of the artist becomes an "operating system”. Its function is to unite what belongs to the will of the subject expressed by the traditional metaphysical concept and the automatic movements of cybernetic bodiliness. If we were to try to get closer to the philosophical attempts of understanding the machine in cyberspace, we would see it as something closest to Simondon's techno-aesthetics. It is known that, unlike the American Cybernetics School with Wiener and Shannon as the principal representatives, Simondon decides to establish an autonomous field of interaction between human and machine. It does not mean an intercession of any humanism with other technical conception. Instead of developing the language and the biological level of consciousness, the problem of human and machine relationship for Simondon is reduced to the relationship of difference and similarity that does not deny the synthetic unity of what it calls transduction. Basically, as Stelarc seeks to preserve the difference between the first and the second nature, starting from the "third-hand" installation, which independently functions as a new entity, while not subjecting it to the biological algorithmic processes of computation, so in Simondon's criticism of cybernetics, he established another kind of difference between machines and humans. This difference is no longer ontological as it was exactly in the early Heidegger's thinking. It derives from the logic of the construction of a technical life as a management system in all areas of society, politics, culture, science, and ethics. And the main method and process in the trans-individualization of Being are precise-hybridization (Simondon, 2007).

There is nothing more of "purity" in natural odours. The path of technical reproduction of creatures through technological replication, of form to cloning as a way of creating an artificial life (A-life) at the time of the rule the of the technosphere, therefore, requires the finding of a new way of connection between the body and what goes beyond its limits. Since the term "embodiment" has thus become ineffective, it is quite clear that for both technique and technology in their principle three-dimensional form (the set-execution concept) must be another logic of the metaphysical foundation of the first cause and the ultimate purpose. The interaction between human and machine not only challenges all the definitions so far from what is the "essence" of human existence, as well as what distinguishes the machine's way of fighting as such. It, moreover, raises the question of the relationship between two related things, and at the same time, seemingly contradictory ways of thinking about art and technique as a relationship between aesthetics and technology. When Stelarc, in his article on prosthetics, robotics, and art explicitly speaks of the necessity of hybridization, then this concept focuses on the 
artistic creation of form and function as the basic concepts of aesthetics. But it is no more "aesthetic" that deals with beauty and sublime. Newton's era of the classical paradigm of science has passed a long time ago. Also, the technique-technology period including the terms of multiplication according to the principles of operational analogy with the nature procedure was too fast. Such mechanical organology, which Marx had as a starting point in the analysis of modern industrial capitalism, was outdated as a biologically predestined human body. In its place already in the 20th century after Einstein, quantum theory and cybernetics became the information technology. With the tendency of creating a new life from the spirit of synthetic biology or biogenetics, it began to penetrate beyond the boundaries of nature (Schmidt, Kelle, Ganguli-Mitra, \& de Vriend, 2009). What were the consequences of that paradigm shift in contemporary science and art that have been already visible at the beginning of the 20th century? There are many comparisons between physics of the particle with the biology of the surrounding world (Umwelt) by Jakob von Uexküll, Einstein's relativity theory and Bergson's metaphysics of durée, Planck's constant and Heisenberg's uncertainty with the perception of the Being and events in Heidegger's and Whitehead's thinking, Riemann's curved space and Cantor's mathematics theory with suprematism of Malevich and the architecture of Le Corbusier. The changes were far-reaching. There is no doubt, however, that they have left indelible traces in the mental landscape of the world.

What might be said related to Stelarc's body? In The Third Hand (1980-1998), the body has been regarded with the prosthesis as

...a symptom of technological excess. A prosthesis is seen not as a replacement but as an addition. The THIRD HAND is capable of independent movements when the electrodes are attached to the abdominal and leg muscles, allowing independent movement of the 3 hands. It has a pinch-release, a grasp-release, a $290^{\circ}$ wrist rotation (CW and CCW) and a tactile feedback system for a rudimentary sense of touch. (...) The THIRD HAND was not intended to be in a fixed position on my arm but rather, in addition to its other functions, was also intended to rotate around my right arm. The THIRD HAND is not merely a visual addition to the body but rather an attachment that generates additional operational and performance possibilities. (Stelarc, 2016, p. 428)

Interpreting Stelarc's experimental art in which the human (biological) body interacts with cybernetic technology, we have to reliably distinguish an interesting explanation given by Arthur and Marilouise Kroker. They, basically, have the intention to analyze the prosthetic body. The radical experiment assumes virtualization, robotization, and suspension of everything that belongs to the purity of biological origin. In that way, the body can no longer understand "transgressive” (A. Kroker \& M. Kroker, 2005, p. 189). It is simply a hybridized case of interaction between the machine and the changed willingness to move in the network environment of the technology assemblies. It would be clear that human might not be understood more metaphysically in the manner of autonomously moving being. Its "essence" lies beyond the anthropocentric aesthetics of the beautiful and ubiquitous. In the case of Stelarc's project/performance Third Hand, we are facing with the radical performing of the "dehumanization of art". That was at large explained in the 20th century by the Spanish philosopher Ortega y Gasset. What is happening in art experimenting with the body as a prosthetics can no longer be the disappearance of "human" from the substance of art. On the contrary, it is necessary to talk about the relationship between substitution and human attachment thanks to the possibilities of the technosphere. That is primarily disputed about objectifying wills. It is well known that it was the decisive word for metaphysics of subjectivity since Schopenhauer. Who initiates the encounter and interaction between human and the robotized machine-the human will in the pure form of entity subjectivity, or the mind, or the extended cybernetic body as an independent field that gives different and new dimensions to what is 
traditionally called the spontaneous act of freedom?

We have already seen that Stelarc's body in the biological sense of being was outdated. It is the primary thing related to the speed and transformation of technologies. By becoming operating systems, they extend to the areas of management of society, nature, and ethics. The "third hand" could be able to testify, among other things, the different possibilities of techno-genesis, unlike onto-genesis. In this special case, the classical metaphysical oppositions of the mind-body, will-moving, and subject-object should be overcome. It would be no doubt so wrong to think that the technical denial is the overcoming of that biological "in" human, as that would mean to suspend emotionality and sensitivity in all aspects. The human genome is not biologically distinct from the genome of the mouse, and its hand from that point of view could not look to the most dominant horse-tail. However, the whole problem of humanity is not hidden in the expansion of physical capacity, but in the improvement of its cognitive abilities. The brain as the decentralized centre of volunteer functions at the same time serves as a biological organ and a spiritual-cultural construction. Therefore, the brain manages the way of life on Earth since the age of technosphere became clear that only through its ethical-political and technological intervention there are still prospects for saving some endangered plant and animal species. Stelarc's research in the interface between brain and machine (biological and technical) has surely gone far beyond altogether working contemporary artists. The reason we would like to propose here is to see that he practically participated in a lab with engineers performing monster robots and virtual avatars. In the trilogy of the meat-metal-code, there is a search for penetration in the technically inhumane and penetrating into that organic human. But now there would be a turning point in the way that organic and technical connect together, creating along the way such complex constellations of strength.

Stelarc has paid special attention to the analysis and performance of the so-called biomimicry. Since in the multitude of form and purpose of the robot that governs the heterogeneity of their relationships towards human, what is surely evident in the way they acting must be the incontinence of the cost of functionality. Like insects, animals and birds, the aesthetic forms of their appearances also differ from what we call the pragmatism of meaning in the semiotics of new media. It does not, therefore, look like (eidos-morphe) something modulates as an idea that decides on the meaning and purpose of existence. Here, we come across with a clear logic of application and use. At first glance, such robots are similar to disarranged monsters. They are fixed on oilfield platforms. They are pretty mobile and dysfunctional at the same time. That is all apparent in Stelarc's Extended Arm (2000). An attempt we really made to distinguish between the modes of a humanoid robot and virtual avatars might be a good step further in theoretical observation. But without aesthetic design as a special branch of engineering or robotics in designing an object that autonomously works and connects alive and non-living, it is impossible to speak about the interface between humans and machine. We have already warned that Stelarc was theoretically sliding on the edge of the differences between posthumanism and transhumanism. That is the way recognizable in the mentioned project. Arm extension signifies a new hand function that autonomously works in the technical environment. However, it might be quite clear that without computer simulation biomimetics cannot be possible. Between what works automatically based on the code and the lively mode of the volitional-emotional structure of action, new relationships are already introduced. That means, first of all, that thanks to the techno-genetic construction, it can accelerate the process of cognitive work of a human-machine as well as expand the field of perception. Consciousness about the phenomenology of physicality always stays intentional. And that quite assumes that the world in the mode of corporeality has to be something in-between unconditional spontaneity of creation and conditionally determined event as construction. 
Being in-between seems to be a real description of that assemblage. If we take into consideration the neurophysiology research that the free will of the subject has never been completely free, as the conditioned reaction of the organism was never a result of unconscious motion mechanics, we should be able to pass through two alternatives: (1) indeterminism of freedom and (2) determinism of necessity in which inhabited the body. Things took in that way still have their own specific relevance, and not metaphysically determined subjects.

In the interpretation of Stelarc's creative technique, American philosopher Brian Massumi shows how to distinguish four types of motion when it comes to the mechanism of the Third Hand. That, of course, also applies to the Extended Arm: (1) voluntary motion; (2) un-voluntary motion; (3) controlled motion; and (4) programmed motion. The first assumes reflective thinking; the second show in the organic field how the functioning of the body cannot be understood mechanically; the third is related to the simulation of electrodes connected to the hand; finally, the fourth indicates programmed gestures of a robotized mode of control. But all that would not be possible without network interactivity that symbolizes visually human and inhuman, organically and technically symbiosis. In the new form of action, the production of relations occurs between separated entities (Massumi, 2002, pp. 89-132). As in the metaphysical way of thinking, it was customary to determine the action of the subject priorly, starting from the ideas and the rules of the mind, so we are faced with a new pragmatism of the meanings of action towards the functional purpose of the object. It must be restrained in the conclusion. Because if it is possible to differentiate voluntarily and involuntarily within the logic of the Being, then it is possible to differentiate everything which should be controlled and programmed within the cybernetic event. However, it would be not possible to establish a strict boundary line between analogue and digital system of thinking simply because Stelarc's intention has to perform a complex configuration of humanoid robots and virtual avatars. And that means that right now digitality is preceded by analogies, but not in the transcendental sense. Empirical world covers in its entirety the facts of human experience. What is truly deployed and what might be the meaning of ontological thinking stems from the idea that autonomous objects of thought created by computer will further programme double encode the sense of human. As the fundamental starting point for aesthetics in all of its manifestations, sensitivity must now be re-constituted if we want to keep alive not only the idea of the contemporary art but also all other aesthetics created in the meantime just like aesthetics of performativity, atmosphere, digitality, etc.

Double coding refers to the experience of a new body presence of a humanoid robot in a common space or a network of interacting communication actors and to the expansion of cognitive capacities of the singularity of human and machine. As it is evident from that ontological-epistemological approach, the object itself now assumes in its power the creation of a new experience of existence in a common (technical) world. Stelarc demonstrated that advancing and developing robots, genetic engineering, engineering, and nanotechnology significantly transform the relationship between body and mind experience. The classic metaphysical "big narrative”, regardless of whether it was Kant or Hume, transcendentalism or empiricism, assumed that the matrix of thoughts and feelings were aesthetically conditioned by the human existence in the world. But everything changes when the suspensions of nature and pure body through autonomous thinking objects in the mutual relationship of voluntariness-involuntary, controlling-programming of movement as conditions of the possibilities of new communication open up finally the question of what the late Wittgenstein is called "Sprachspiele". Language is no longer a means of expressing opinions, so it cannot be accommodated with the substance of technique. Likewise, the language could not reproduce reproducibly as it belongs to the very core 
of modern technology. Instead, language as a pragmatic guide to changing situations and contexts describes what is happening (quodditas) and did not express what is being as being (quiddittas). In that respect, it should be expected that the languages of the human and machine interface will evolve to the symbiosis of the natural and technical languages of the new pragmatic knowledge about the contingent "Being" in the world. In it, there are plants, animals, humans, robots, cyborgs, and androids next to each other (Broadhurst, 2007). If in the analogy, the experience and sense of sensitivity were mutually separated, hence the analytical method of deduction of mind and feeling seemed to be the relevant access and technical reality; in the digital world, it is now integrated into an integrated circuit. Consciousness is not an imitation of Being as nature in terms of logical deduction and aesthetic mimesis. It should be mediated after the turn of the subject's idea into the mindset of the object. This facility works, however, controlled-programmed, as Massumi carried out Stelarc's experimental constructions with the construction of humanoid robots in interaction with their own singular body.

Instead of the passive synthesis of consciousness and Being, we are facing in close connection with an active synthesis of a new sense of experience. All that is still happening on the fundamentals of calculating, planning, and constructing of the technosphere. Therefore, it is necessary to apply the suspension to the concept of aesthetics as a philosophical discipline on the art and sensitive world. When they are no longer at the centre of the analytical courtesy of things and beings, the synthetic trial of the technogenic circuits of human and machine relations should use the concept of integral synesthesia. It includes distinct concepts of insensitive sensitivity to plants, animals, humans, and cognitive machines (robot-cyborg-androids). What is synthesized here we may call also synesthetic in the sense of a technically-produced way of thinking and feeling of the world in which the interplay between the "A-intelligence" and "A-intuition" are really governed. Stelarc's works/projects, such as Fractal Flesh (1995), Ping Body (1996), and Parasite (1997) are performance based on the experience of a hybrid body under cybernetic control and programmed information code (Stelarc, 1997).

Movement of Stelarc as a biological body of a single member of the "man" type is also spontaneous and derived from the management system that derives from the will of artificial intelligence. Unlike the speculative metaphysics of German idealism, "will” can no longer be derived from the inscrutability of the idea of a modern subject. After all, what the "will" wants, what it wants in a plan is to conquer the space-and-time. Consciousness is based on the idea of the unconditional subject "will" that Descartes and Leibniz called self-proclamation. It absorbs all of its affectations and physical objects. In that way, the subject starts an absolute ruler over the body. In all possible situations, the subject is dominated by the environment. Using nature for its construction landscape, transforming it into power and terminal, and opening Pandora's box of monsters, the subject thinks and creates its new environment by the performing of technology. Without the idea of the subject as an unconditional will for the victory of the Other (the Being as Nature and hence "being" of a human) cannot be constructed of modern aesthetics. Heidegger was right when at the end of the 1930s, in the lectures on the notion of the event (Ereignis), he repeatedly pointed out that behind the magnificent façade of aesthetics stands nothing but mere "illusion" and "experience" of the sensual world. Is there something more monstrous if we need art only as a substitute for the disappearance of gods, beings and nature? (Heidegger, 2009). However, the underlying problem of that new sensitivity without "sensitivity" or sensible sensitivity, which would have the essential properties of human suffering and awareness of it, is that the singularity of the human species could be met by the collective singularity of the machine. If the quiddittas in question was a condition of ontology, then it would be a rebound to anthropology, but how does one determine the question 
that pretty and very distinctive way? Simondon himself stated that "the robot does not exist". Wittgenstein, on the other hand, has assumed something quite different from the (human) language for the essence of animal communication. The beings are the beings created by nature and technique, though, ontologically different. But the difference should not be just as it was in old-fashioned metaphysics. It is always, of course, derived from the metaphysical rank of the judge of the difference. A human with God shares common authority by judging what is being and who is who. In any case, the space of interaction becomes the networked activity of the robot as a thing that thinks in a manner of algorithmic command and control system. Consequently, what Stelarc has done so far in his experimental triads of meat-metal-code has not yet reached the extreme limit of aesthetics. It can be argued that the stage was not established until the Chilean biologists and neurocognitive scientists Maturana and Varela in the early 1970s to construct new scientific areas by the discovery of autopoiesis theory (Maturana \& Varela, 1980).

That could be a path to the contemporary cybernetic artist Ken Rinaldo is taken, known primarily for his interactive installation entitled exactly the same as the main concept Autopoiesis (Rinaldo, 2000). The artist, by explaining it auto-reflexively, attempted to create a series of fifteen sculptures of artificial life $(A L)$. All of them are constructed in an interactive immersion environment. In that sense, artificial life $(A L)$ should be understood dynamically as the assemblage of technology and biology (Rinaldo, 2016, as cited in Stelarc, 2016, pp. 116-147; Grau, 2003). But it could work only by acting in a controlled and programmed environment of interaction. Musical and robotic sculptures have the function to jointly participate in the individual and group awareness of networked robots. It is not difficult to find that Ken Rinaldo, unlike other similar ventures, including Stelarc, directs something essentially different from the techno-genesis. It is, in fact, a reflection on the integrity of a differently structured totality of behaviour or interaction of living organisms and living systems with technical systems. Moreover, the cybernetic fundamental setting of symbiosis and homeostasis of the system and the environment here is sought to be understood starting from the concepts of self-organization, emergence and complexity of life as such. As the relationship between the living and the technology within the cybernetic network has been established, Rinaldo comes from symbiotic unity. In it, machines, animals, plants, bacteria, and humans share information and communicate with each other. Taking the theoretical model of its artistic preoccupations the model of common evolution of intent is to open the problem of encounter and transformation of biologically defined species. This is no more method and hybridization process as it was self-explanatory for Stelarc. It seems that Rinaldo, along with Maturana and Varela, could be the closest to the theoretical experience of the American feminist anthropologist Donna Haraway.

Her understanding of posthumanism, the close relationship between species is found in a completely different way than it was during past history. In the book When Species Meet, Haraway (2007) claimed that the question of the relationship between living beings as an animal requires a simultaneous abandonment of subjectivity and biology on the outcome of metaphysical anthropocentrism, but not in the way of Heidegger's reaping of the period of planetary nihilism. Instead, it might be necessary to establish a common kind of unity and synthesis of differences, starting with the new sensitivity. Its place is within the cybernetic network of events. What that means, in particular, is apparent from what Rinaldo explicitly seeks for the transcendence and experience that is created. It is by no means surprising that in the age of technosphere, the age-old dispute between the mind and the body means the dispute between the human and animals, including the plants, again leading to a completely different level of thought. The term used here to suppress the experience of suspending and neutralizing everything that is still alive is called symbiogenesis. In the inevitability of the penetration of 
machine thinking into the structures of life, a new form of interaction demonstrates the need to abandon traditional metaphysical schemes. Therefore, the interface between human and machine would not be the only communication that requires a different explanation.

Rinaldo (2016) said that "the central focus of my artwork was to work with the machines, animals, plants, bacteria, and humans" (p. 115). This inter-communication assumes the demolition of a hierarchically determined by order of being. In addition, it is about returning to the dignity of those beings who, because of the emphasis on the notion of the human mind as the centre of the subject, were most excluded from the dominant discourse of social and human sciences. Let us remember that the overcoming of metaphysics of logocentrism began with Derrida's (1967) main early work. It seems to be a paradox that the true communion of a different kind could be only possible at the "end of history". Thanks to the autopoietic system of the technosphere, anything becomes possible. Finally, all that has been accomplished beyond Hegel's dialectics and its inherent concept of contradictory synthesis. With the emergence of computer technology, a network was created simultaneously for all possible interactions between the system and environment. In endo-symbiogenesis, as Rinaldo concludes, based on the scientific analysis of the DNA expert, biologist Lynna Margulis, there are different relationships between a quite different species. If the prior period of biological evolution was Darwin's theory of choice of natural selection, and that is only just different translation of Nietzsche's will to power beyond the mere survival of the Earth, then in the age of technosphere, that "iron law" of irresistible power goes beyond on a stronger, more subtle, and superior strength existent in a series of species. The question of survival is no longer a matter of the brutality of aggression and of the substitute of cultural adaptation strategy. Thanks to the information code governing intelligent life systems in interaction networks, the main question is that: How to preserve the biological and genetic diversity of the beings on Earth by preserving the species? Rinaldo's understanding of the transversality of an artwork assumes systems of biologically diverse beings and interactive robots. The key term is related to the "new interface". Installation sculptures interact with each other in real-time interaction. In the case of paradigmatic work, Autopoiesis can show that fifteen sculptures change their forms of communication depending on the movement of one of them. The most important thing, therefore, might be the emphasis on self-organization and self-defence. This proved a cybernetic setting of open structures and the open machine. What, though, is determined as the important difference in which is almost the same according to the idea of interaction between humans and machine performed by the work of Stelarc and Rinaldo? From the formal standpoint of recognizing the mode of expression in contemporary art, it is first oriented towards the performance of performativity. By contrast, symbiogenesis signifies the horizontal self-tractability of all creatures in the co-evolutionary model (macro and micro-levels of appearance). In addition, Rinaldo decides on the form of an autonomous building installation, not the interface of the human body and the machine. The sculpture as an interactive object to a technologically advanced human body is related to an extended vivid singularity toward the frozen body in a series of meat-metal codes. What is specifically explored here is nothing but the emergence and transformation of the condition from passive to an active observation of events. The spectators are observing their emotions. That is the way how participation in an interactive event turns into a contingent array of unpredictable reactions. Autopoiesis, however, is represented as a logical sequence of Rinaldo's previous cyber-installations, such as Mediated Encounters from 1996. It would be always a matter of incorporation in the social order of meaning and in the cultural landscape (scape). But where did a robotized installation in the space has its own place, pertinence and instability in mutual symbiogenesis? (Candy \& Ferguson, 2014, pp. 81-82). 
What Rinaldo himself calls "the cybernetic ballet of experience" affects the encounter of observers with the installation of space (computer) media (Rinaldo, 2016, p. 126). It is visible to explore the boundaries of self-consciousness as the living presence of human personality and coded programs of artificial intelligence (AI). Therefore, these sculptures in their mobility are "bio-cybernetics". The principle of analogy links the biological structures with simulation technology. However, it seems that the notion of simulation that in the theory of new media has gained the highest level of abstraction through Baudrillard's theory of "real agony" and the rule of simulation in a globalized world is quite ineffective for far-reaching autopoietic action. Firstly, it would not be self-actualization but a feature of living systems. Autopoiesis refers to the open structures of technologies in the construction of virtual events. Everything virtually has the ability to update itself. Gilles Deleuze exactly has been done that thing in early texts dedicated to the problem of new ontology with the key concept of becoming. When something is self-organized and can only be redirected by itself without the help of external or internal triggers in terms of cause and purpose of movement, we can really speak about the "plane of immanence”. That essential philosophical notion in Deleuze's turn of classical metaphysics presupposes not only the denunciation of the logic of causality and the principles of teleology. The whole order of meaning is now being reorganized. And that is the way how differences and contingencies should create a new constellation of relationships and other contingencies.

In the case of Rinaldo's installations and the ideas of transcendence, we cannot speak about simulation simply because, as a result of the technosphere, the entire bio-cybernetic order takes place of autopoiesis, moving towards a "metastable balance" if we decide to use the key concept of Simondon's ontology. Then, it can be concluded that the relationships between "living" and "biocybernetics" are beyond the logic of imitating nature. Robotized objects are triggered by A-intelligence. Therefore, all relationships between plants, animals, bacteria, and humans are completely altered. In 2005, in co-operation with Matt Howard, the Autotelematic Spider Bots have been true proof of the previously stated thesis. The sequel to related art research by Ken Rinaldo took place in the 2011 Fusiform Polyphony installation in Toronto and Sao Paulo (Rinaldo, 2011). There seems to be a question here in the relationship between the robot and the structure of desire with respect to the body. Six interactive sculptures produce their own music in the encounter with participating interactive faces. How could something like that be possible at all? The micro video cameras are mounted on the robots and are triggered by the movement of the robot by capturing changes in the observer's faces. Changes in the faces create sound melodies, tones, and rhythm. What does that installation really want to investigate? The answer is obvious: just the way how robots seeing human reactions and not vice versa. Entering into the deep structures of the thinking and perception of the Other as a biocybernetic object was an ancient dream of philosophers and artists. What is enabled by the technical capabilities of the technosphere now shows an autonomous field of interaction between different corporeal experiences and different sensitive thinking. What is accomplished with that? For Rinaldo, it runs along the way to a symbiosis of nature and technology. But it all that takes place only without the last instinct in which systems of living need to cuddle in the wake of the technological meltdown of modernity. The problem might be, as it is done similarly for Simondon, that it is trying to preserve some kind of sustainable development of tolerance between the worlds of plants, animals, bacteria, machines, and people. That sounds like biocybernetic utopia with good intentions of environmentalism. Yet, it would be necessary to remove the conditions that in various forms of being lead to an intolerable logic of will to power. If all species are not aggressive then they must be possessive. That could be already enough to devastate the Other even when it would be respected in the name of repressive tolerance and 
the cult of difference. Objects show already by their acting in the interactive network of events the desire for action, the active-passive synthesis of contradictions, the overcoming and reacquisition of the territory of the Other, even though the latter was a supreme angel or robot, which according to Simondon does not exist, but have "alive" autonomous objects. In the metaphysical speech, we are facing pure evil as an impeller of turbulent historical events. What should be noted about the initiator of an interactive conflict between trans-species in the technical world, is it that the will to power or desire to lead the collective singularity of Being? Let us now leave that question unresolved, without any allusion to the scenes from SF-utopia and dystopia related to Alien, Star Wars, and Star Trek.

\section{Worlds of Autonomy of the Object}

Without the notion of information, there would be no cybernetics, open machines, autonomous objects, and experimental art with sensory boundaries at all. Moreover, it would not even be possible to imagine how to force the machine to become autopoietic. It is well-known that Norbert Wiener separated the information from matter and energy. In this way, every apotheosis of "materialism" and "realism" in contemporary communication theories makes outdated perceptions that require some kind of "Big Other" or transcendental signifiers, such as "capital”, "work”, “society”, and "politics” to have an illusion of "objectivity” and credibility in the complex processes of the emergence of new worlds. All that, however, sounds like the resurrection of the ghost without any argumentation sense. What makes contemporary artists, such as Stelarc and Rinaldo, goes far beyond the illusion of the new materialism with various additions, such as "speculative”, "cognitive”, etc. The information goes beyond the limits of materiality and energy. Hence, the reason is that its form or shape (eidos-morphe) did not hide in the structure of an autonomous object that thinks like robots-cyborg-androids. Instead, we are confronted with the division of information as language, theory, and technology. That is, in most circumstances, the main reason why the symbiosis of living and technical in the form of an autonomous object of the cognitive evolution universe represented a sign of overcoming almost everything that defined the fundamental notions of modern aesthetics: (1) the senses; (2) the world; (3) and mind as an imagination. When that "sacred trinity" emerged through the construction of the machine of thought by the emergence of cybernetics in the twentieth century, there was a period of reign of the unconscious organ in keeping sensation alive, as conceptual tools in Artaud's and Deleuze's thinking were useful for our better understanding of the magical technical world (Paić, 2019). What did all that matters really means for the idea of contemporary art?

Let us, above all, praise in advance the phenomenological perception of the body in the expansion of early Heidegger and its concept of Dasein as In-der-Welt-Sein on the physical existence of human-in-world as expressed by Maurice Merleau-Ponty. Not only phenomenology but even more psychoanalysis in all its discursive forms, in the collision with the technical world can no more be any significant matter to our cognitive patterns. That is something that Walter Benjamin maintained in close connection to the interpretation of Kafka's literature: In fact, there is an equal rank of mismatches of interpretation which has been searched a God or unconscious trauma (theology and psychoanalysis). It should be necessary, in addition, to start from something that opened and simultaneously closed the space-time of the technosphere. And that can be nothing more but a new "sacred trinity" of cognitive powers in the form of transformation the reality, such as (a) events; (b) contingencies; and (c) chaos. However, it might be necessary to warn that we did not operate with logical-historical categories. If the event opens a new horizon, it is doing so only in the empty sky which did not belong to the Being, we encounter its uncanny indefiniteness. Nothing more is no longer mere facticity. 
However, the sensitivity cannot be determined otherwise except by biotechnological experience. That is the same what Stelarc's and Rinaldo's attempts used to be. We may describe the event also as a contingent set of computing, planning, and constructing thinkable objects. Their autonomy, on the other hand, tends to sink into the monstrous possibilities of self-creation. Without the help of external or internal common cause of movement (probability), that process takes own place. And precisely not only that the metaphysical organization of the Being-God-World-Human break into debris, but the very idea of contemporary art as a project, method, and experiment is derived from the technological and technological construction of new worlds. The chaos might be understood, of course, from what Deleuze and Guattari described in What Is Philosophy? (Qu est-que laphilosophie?), on the trace of Joyce and quantum mechanics characterized by the possibility of the metastability of the order (Deleuze \& Guattari, 1991/2005, pp. 189-206). Today, we call that economic and socio-cultural assemblage "information nexus: global capitalism". If there are much more chaotically circumstances on the road, the order should be pretty more stable. That is not, of course, an absurd assumption. The term chaos within the new cosmological speculation has primarily the features of contingency and entropy in the open system. So, the breakdown of the order doesn't appear to be a necessary consequence of some insurmountable cause. Let us logically conclude that nothing will crush down the state of disorder and ruthlessness of matter and energy. On the contrary, chaoticity becomes a necessary measure of metastability. Neither the line nor the mess, but the chaotic order of mutually coordinated network of events belongs to the new concepts of modern technology. And then, as a consequence, it is exactly the case also for the complexity of contemporary art (Rössler, 1998, pp. 13-20). To say that it still has "autonomous” spiritual power in relation to science sound totally fake and absurd. Both science and art are differently articulated spiritual powers in the service of autopoietic "progress" and "development" of the technosphere. Nothing more and nothing less!

If everything became artificially alive in that order, and the subject move to the logic of the construction as we have seen in the works of leading contemporary artists in the age of technosphere, then it would be self-evident that all existing differences have been abandoned. That occurs in the time which accepts quite another model of thinking the matters of what the author prefers to call cybernetic difference. It is no longer the difference between the world and human, God and human, human and animal, and subject and object. Instead, we are witnessing the emergence of new differences in the "essence" of the techno-genetically structure of the worlds. The new difference, however, stems from the complex configuration of the situation and the event. Instead of the order of substance and their attributes, the order is now based on stability in change. Therefore, the idea of contemporary art and its derived aesthetics goes beyond the existing boundaries. In the process of hybridizing substances and beings only what seems to be "pure" belongs to the process of creating new spiritual information. Determining the "essence" of contemporary art merely by the simple continuation of the paradox and the avant-garde in the 20th century does not seem more instructive. First of all, because the contemporary art is energetically placed in the centre of the dispute and in the relationship between inventiveness and creativity, it is not difficult to find out that the time and space in which events occur as works of contemporary art are related to virtual realization in real-time. Here, the world of objects like institutions and their complex have ruled only as a reference to the lost materiality of the technosphere, nothing more. It did not mean to be-present "here" and "now" in the sense of classical Aristotelian metaphysics. Without the unity of space and time, everything seems to be virtual in performance. It will be possible to be "here" and "there" and at the same time to be "here" and "now". Our daily experience clearly confirmed that fact. The telepresence experience is thus enabled by the cybernetic transmission of distance information. But that is not all what we 
still have to say. When things become smooth and unobtrusive it might be a sign of dematerialization of the world. Everything is mixed with each other. It thus becomes a network of information in the infinite sequence of variations. Returning to a point of departure before transforming into the world of autonomy of the object that thinks and acts interactively would be like a new return to Plato's cave after we saw the dazzling sunlight. In the elevated moment of reaching the singularity, every step backwards testifies to the fear before the penetration into the coming brag. There is no return any more. All deeds are irretrievably missing. However, the technosphere has freed the path to the kingdom of the creative (de)structure of the worlds. Has not this liberation created new unconditional slavery of ideas without which everything would be imaginatively astonishing, yet desolate and empty?

There would be something else in the release of human aesthetics. Stefan Rieger talks about some other ways of understanding electromagnetism. But not just as technical knowledge about storing information, nevertheless in direction on "electrification of knowledge of human" (Rieger, 2002). By extending the meaning of the living body, synesthesia becomes unconscious. Simply speaking, all the techniques that have been applied since the 19th century to preserve the integrity of human's body structure have been directed to sensitize an increasingly intense emotion by means of technical training. Therefore, the question of aesthetics in the age of technosphere should be the question of overcoming the limits of human sensitivity. It does not mean only the feelings of observing the outside world. First of all, it carries out on the "physiology of the soul" as the vibrations of what accumulates to a high level of discourse. Nietzsche was the first to announce it. Let us also remember what reconsidered as the subject of modern literature. Lawrence Durrell in tetralogy The Alexandria Quartet enters the psycho-structure of Clea's self-conscious painter. After accidentally she lost her hand, continuously uses a substitute, mechanical, or "third-hand" in painting as an artist in the same manner as almost automatically performed a surrealistic writing-technique. In addition, her new experience seems almost ecstatic. The question of freedom of will in the condition of the technical device becomes more than the question about the limits of consciousness between human and machine. The aesthetic can, therefore, be extended even after the "end of human", but only under the condition of moving to the zero points of selfishness. However, "beauty" and "sublime" are no longer attributed to the subject. Instead, the work is the total aestheticization and self-consciousness of the object of thought as a creative and productive, and, why not, performing autonomous object. Aesthetics is finally transformed into aestheticism and thinking into cognitive protocols for predicting events based on algorithmic accounts (computations). That turn introduces the openness of the new corporeal experience. We can say however, that is the reason why are concepts inherited from phenomenology and psychoanalysis no longer usable. The body in the aesthetic mode of production of thought goes beyond the intentionality of objects and traumas of real. It is the openness of self-assessment within the framework of continuous transformation. And when something is open in its own way, it cannot be predicted how the development of ideas would look alike. That's a significant difference in metaphysics. Now, the process takes place in fluid signs of pragmatic thinking. Nothing has its purpose in advance. Instantly and constantly unchanging being and the creation of a new reality are transformed into a conceptual architectonic based on the idea of the persistence and immutability of the Being-God-Human-World. Faced with radically change Being is replaced with available aesthetics instead of pure beauty. In the decay of metaphysics, only the transfiguration of its cunning debris is going to be completed. That process finally is being crossed today into the final stage of realization. 
What is left of an undefined area that may determine an undesired experience of pain? The feeling of pain appears necessarily as a reaction to external pressure on the body. Ranging from stinging and tingling of the womb, skin rupture, neuronal irritation, and body breakdown, the pain is physically recorded on the scale of intensity. The work on overcoming it is represented an important task of posthumanism/transhumanism. After all, in contemporary art, just researching the limits of pain as suffering shows the question of inscribing various taboos and cultural patterns on the body. With the suspension of bodily pain, the new experience now manifests itself in the mode of strong intensity. The interactivity between autonomous objects has appeared as the mystery of communication. "The machine as an autonomous performer" takes over the powers of the living body (human-animals). But that only continues the drama of becoming a new one in the form of cybernetic corporeality (Bown, Gemeinboeck, \& Saunders, 2014, pp. 75-90). There are no more patterns of repetition of "nature" in its evolutionary movement from the first cause to the ultimate purpose. The pain and suffering of bodily singularity can no longer be lengthened in the absence of constant transformations of the new. What is valid for the ontology of physical sensitivity to the human model and its position in the universe would not be in the same way a feature of the "existence" of the technical creation/thing. In the form of an autonomous object, its "life form" must be understood from the undeniable hyperplasticity of movement management and interaction with other species. The pain, therefore, seeks to overcome even before any human sensitivity has emerged in the new garment. Peter Sloterdijk announced that strategy of posthumanism/transhumanism already in the book Thinker on Stage: Nietzsche’s Materialism (Der Denker auf der Bühne: Nietzsches Materialismus). With the term algodicy, he was trying to oppose to famous Leibniz's theodicy. According to Leibniz, evil exists at the end of history but vanished out of God's act of grace. Therefore, the sufferings become redeemed in the blessed eternity. In addition, algodicy works "here" and "now" thanks to the progress and development of intervention of technology in the human body structure. By the combination of medical and psycho-pharmaceutical methods and degenerative disease removal procedures, life was established by fundamental value. Physical self-improvement in terms of substitution is thus becoming a specific new norm (Sloterdijk, 1986, pp. 160-170). The technical strategy of overcoming metaphysics did not mean that the body has been replaced by the spirit. It would merely be vulgar materialism of the new blade. Without the justification of the freedom of spontaneity of human activity, the body would not be able to think. Moreover, what gives the body its power of movement could be only the will to move away. The freedom precedes necessity and not vice versa. It was evident to Marx when the idea of capital determined the perversion of the primordial relationship between human and nature. Thus, the body thinks all the time in a comprehensive bio-cybernetic horizon as a set of contingent events starting from a new definition of life beyond biology and zoology, anthropology, and psychology.

\section{Conclusion}

What does that body want if it does not scream like a hysterical Pope in the chair of the canvas painted by Francis Bacon? The deformity of the pain repertoire in all vibrations of intensity did not mean that body weight has lost the weight of rootedness in the flesh and the nerves, turning to the angel dance of the heavenly spheres. The thinking needs a placenta and the environment packed with bodily inscriptions. Let us recall from Nietzsche to Cioran that suffering from the Greek term agony to Christian theodicy with Christ's seal of the power of the cross and the miracles of resurrection raises to the conditions of an opportunity of thinking beyond the everyday life of mere life. After all, for Alfred N. Whitehead, the act of Christ's crucifixion was a grand 
event not only of a different understanding of history but rather of creating a new one in the perpetual transformation of the Being (Whitehead, 1929-1978, p. 338). Placing the body in the centre of the reflection means radically breaking with the unnecessary complement of all those terms that gave justification to the metaphysical missionary. Among them, pain and suffering must have had most of the share in the image of the sublime as a monstrous ecstasy of beauty that language can never reach. But the time has been the pain of suffering as a fuel tragedy of history. The body now doesn't have its solution in the metaphysical program as the soul/spirit organ for moving and sensitive re/actions. Its ecstatic sensitivity becomes a technical construction realized in a "form of life" that can even be freely chosen. Inasmuch, it should be necessary to find the appropriate terms and categories for that "fisting" process. It deals primarily with transhumanism. However, if anybody doing that by means of 3D printing of replenishing organs, then "resurrection" of long-erased species like mammoths that the cloning methods of frozen stem cells are trying to revive, and ultimately attempt to reach the secret of immortality with the aphid. The philosophy that devoted special attention to the body in the 20th century seems to have played its own important part. Let us compare, for example, the settings of the analytical philosopher and theoretician of contemporary art Arthur C. Danto about the incarnation and the physicality of what the preoccupation of transhumanist scientists will see could be a pretty well significant difference. Danto, regardless of the syncretic background of Hegel and Wittgenstein, still understood the body with the mystery and fact of existence in the world. On the open horizon of appearances, he relied on its own self-certitude (Danto, 1999).

But for the transhumanist body, it might be the meaning of digital uploading. It is treated rationally and instrumentally to extend "lifespan" with the technical implants. What remains in all that we may say putting in decisive question: How to think of the difference between the world's secularity in which the body appears as a contingent event and has been constructed as a simulacrum? In the language of Kierkegaard's existential analytic of suffering and love, we recognized the difference between singularity and reproduction, and original and creative copy. The direction is reversed. Now the last is to determinate the first as a possibility of reconstruction under different conditions. The reproductive singularity of the technosphere towards the body should not restore the dignity of the original in the system of multiplication of aesthetic objects (readymades). One step further in the direction of the immediate future that is already happening might be the idea of repeatability of the body's incompatibility as a technical construction. In an experimental design game with interactive robots, Stelarc has remarkably shown why the human body belongs to the Anthropocene period. As a matter of fact, modern civilization has reached its own end. The same applies to Rinaldo's biocybernetic sculptures deeply immersed in the virtual space in real-time. There is no more sufficient reason for contemporary art to return to some imaginative outcomes before it has, for the first time, turned Malevich and Duchamp into the path of total dematerialization. Its fate would be resolved in the repeatability of the contingency of technosphere. Of course, there is nothing else to propose for a "new beginning", because something is missing regarding the myth and religion as referential frames. From the modern age, it might be only the "progress" and "development" of the image as the world and the world as the image. All other alternatives have been invented except for the technique as "unhappy disgust". Further, all that was already done by the disappearance of the Greek world, which aesthetics did not need to justify living creatures embedded in art plastic and architecture. When, however, the synesthetic new sensitivity will be enumerated in what is happening today, in technologies and techniques, we will able to speak about redesigning the world. 
Unidentified relations are ruled by space-dwelling autonomous objects. There is no doubt that this was announced by the F. T. Marinetti in the Futurist Manifesto in 1909, where the fast car is more beautiful than the ancient Greek goddess. But while still having the utopian absurdity at the beginning of avant-garde art in the twentieth century, today it has become an expression of the merging aesthetic object and post-conceptual art. When the machine as an autonomous object tends to drive itself and at the same time launches wherever it wants, a "big narrative" of technological development, computing, planning, and construction of the world is completed. What remains we will simple determined by the "cosmic dance idea" in the game of the world as such. It looks like what Hegel described in a poetic-speculative way when he directed the last word to an Absolute, who just like Heraclitus's child, still play the game without anyone. But unlike the first and the foremost beginnings, the Absolute no longer creates and destroys unreasonably and unconditionally. Just here and now everything happens as an experimental game of computing and visualization of events that are lower than ever. As long as the distant horizon of absolute closeness takes that empty and distant time, the time of boredom and nihilism is coming, without beginning and without ending.

The age of technosphere seems to be quite absurd time without last metaphysical secret. Let us imagine, then, the "infinite speed" whereby an object collapses into the darkness, and instead of the horizon there are only white holes in the open sky.

Paul Valéry once wrote: "Reality is still in balance with the nonsense of all its own dreams".

\section{References}

Bense, M. (1978). Estetika (Aesthetics). (Translated on Croatian by RadoslavPutar). Rijeka. O. Kersovani.

Blumenberg, H. (2015). Das Verhältnis von Natur und Technik also philosophische problem. Frankfurt am Main: Suhrkamp.

Bown, O., Gemeinboeck, P., \& Saunders, R. (2014). The machine as autonomous performer. In L. Candy and S. Ferguson (Eds.), Interactive experience in the digital age: Evaluating new digital practice. New York: Springer.

Broadhurst, S. (2007). Digital practices: Aesthetic and neuroaesthetic approaches to performance and technology. New York: Palgrave Macmillan.

Candy, L., \& Ferguson, S. (Eds.). (2014). Interactive experience in the digital age: Evaluating new digital practice. New York: Springer.

Danto, A. C. (1999). The body/body problem: Selected essays. Los Angeles, London: University of California Press.

Deleuze, G. (1989). Cinema 2: The time-image (H. Tomlinson and B. Habberjam, Trans.). Minneapolis: University of Minnesota Press.

Deleuze, G., \& Guattari, F. (1991/2005). Qu'est-ce que la philosophie? Paris: Minuit.

Derrida, J. (1967). De la grammatologie. Paris: Minuit.

Grau, O. (2003). Virtual art: From illusion to immersion. Cambridge, MA: The MIT Press.

Haraway, D. (2007). When species meet. Minneapolis, London: University of Minnesota Press.

Heidegger, M. (2009). Beitrage zur Philosophie (Vom Ereignis). Frankfurt a. M: V. Klostermann.

Kant, I. (1979). Kritik der Urteilskraft. Werkausgabe. X. Frankfurt a. M.: Suhrkamp.

Kroker, A., \& Kroker, M. (2005). We are all Stelarc’s now. In M. Smith (Ed.), STELARC: The monograph. Cambridge, MA: The MIT Press.

Lipovetsky, G., \& Seroy, J. (2013). L'esthétisation du monde: Vivre à l'âge du capitalisme artiste. Paris: Gallimard.

Lovejoy, M. (2004). Digital currents: Art in the electronic age. New York and London: Routledge.

Massumi, B. (Ed.). (2002). The evolutionary alchemy of reason: Stelarc. In Parables for the virtual: Movement, affect, sensation. Durham \& London: Duke University Press.

Maturana, H. R., \& Varela, F. J. (1980). Autopoiesis and cognition: The realization of the living. Boston: D. Reidel Publishing Comp.

Mersch, D. (2002). Ereignis und Aura: Untersuchungen zu einer Ästhetik des Performativen. Frankfurt/M: Suhrkamp.

Moore, M., \& Vita-Moore, N. (2013). The transhumanist reader: Classical and contemporary essays on the science, technology, and philosophy of the human future. London: Wiley-Blackwell. 
Paić, Ž. (2011). Posthuman condition: The end of human and odds of other history. Zagreb: Litteris.

Paić, Ž. (2019). White holes and the visualization of the body. New York: Palgrave Macmillan.

Purgar, K. (2006). End of the transgressive body-Interview with Arthur and Marilouise Kroker. Tvrđa, No 1-2. Retrieved from https://www.visual-studies.com/interviews/kroker.html

Reichle, I. (2009). Art in the Age of Technoscience: Genetic Engineering, Robotics, and Artificial Life in Contemporary Art. Wien-New York; Springer.

Rieger, S. (2002). Die Ästhetik des Menschen: Über das Technische in Leben und Kunst. Frankfurt a. M.: Suhrkamp. Retrieved from http://www.kenrinaldo.com/portfolio/autopoiesis/http://www.kenrinaldo.com/portfolio/fusiform-polyphony-face-music-toronto-2011/

Rinaldo,K.(2000).http://www.kenrinaldo.com/portfolio/autopoiesis/;

http://www.kenrinaldo.com/portfolio/autopoiesis/http://www.kenrinaldo.com/portfolio/fusiform-polyphony-face-music-toron to-2011/

Rinaldo, K. (2016). Trans-species interfaces: A manifesto for symbiogenesis. In D. Herath, C. Kroos, and S. Stelarc (Eds.), Robots and art: Exploring an unlikely symbiosis (pp. 113-147). Singapore Media: Springer.

Rössler, O. E. (1998). Endophysics: The world as an interface. New Jersey, London: World Scientific.

Schmidt, M., Kelle, A., Ganguli-Mitra, A., \& de Vriend, H. (2009). (Ed.). Synthetic biology: The technoscience and its societal consequences. Heidelberg, London: Springer.

Sloterdijk, P. (1986). Der Denker auf der Bühne: Nietzsches Materialismus, Frankfurt a. M.: Suhrkamp.

Stelarc. (1997). http://www.medienkunstnetz.de/works/fractal-flesh/; http://www.medienkunstnetz.de/works/pingbody/; studioforcreativeinquiry.org/projects/parasite-a-performance-by-stelarc-1997stelarc.org

Stelarc, S. (2016). Encounters, Anecdotes and Insights_-Prosthetics, Robotics and Art. In D. Herath, C. Kroos, and S. Stelarc (Eds.), Robots and art: Exploring an unlikely symbiosis. Singapore Media: Springer.

Virilio, P. (1991). The aesthetics of disappearance. (P. Beitchman, Trans.). New York: Semiotext(e).

Welsch, W. (1996). Grenzgänge der Ästhetik. Stuttgart: Reclamm.

Whitehead, A. N. (1929-1978). Process and reality: An essay in cosmology. New York: The Free Press. 